\title{
Factors Influencing Student's Satisfaction in the Physiotherapy Education Program
}

This article was published in the following Dove Press journal:

Advances in Medical Education and Practice

\author{
Melaku Hailu Temesgen (D) \\ Yisak Girma ${ }^{2}$ \\ Tamiru Dugo ${ }^{2}$ \\ Getachew Azeze ${ }^{2}$ \\ Mihret Dejen ${ }^{2}$ \\ Melkamu Deres ${ }^{2}$ \\ Balamurugan Janakiraman (D) \\ 'Department of Physiotherapy, School of \\ Medicine, College of Health Sciences, \\ Mekelle University, Mekelle, Tigray, \\ Ethiopia; ${ }^{2}$ Department of Physiotherapy, \\ School of Medicine, College of Medicine \\ and Health Sciences University of \\ Gondar, Gondar, Ethiopia
}

Background: Despite the expansion of the physiotherapy program over the past decade in Ethiopia, there is modest knowledge of the extent of physiotherapy students' satisfaction. This study was conducted at the Department of physiotherapy, University of Gondar in Ethiopia.

Purpose: The objective of this study was to assess the satisfaction of students with the teaching and learning process and to identify the factors influencing course satisfaction amongst physiotherapy students. This questionnaire survey investigated the effects of demographic variables, perceptions of satisfaction, and education-related parameters on the level of student satisfaction with their educational experience.

Methods: An institutional-based cross-sectional study was conducted by recruiting entrylevel physiotherapy students during 2018. Data were collected from a sample of 173 physiotherapy students using structured and validated self-administered Students Satisfaction Questionnaires. Logistic regression model was used to identify factors significantly associated with student satisfaction in the teaching and learning process.

Results: Out of 173 participants, most of them 112 (64.7\%) were male and the majority of them $(37 \%)$ were third-year students. The overall student satisfaction was $33.1 \%$ for all categories. Awareness about physiotherapy education before enrolling into the physiotherapy educational program (AOR 6.3, 95\% CI: 2.2-17.8), year of study (AOR 0.12, 95\% CI: $0.02-0.67$ ) and availability of classroom furniture (AOR $0.05,95 \%$ CI: $0.04-0.66$ ) were statistically significant associated factors for student satisfaction.

Conclusion: The overall student's satisfaction on the learning and teaching process was low, in particular, the satisfaction for the clinical training is also below par, which is a major concern. Area of intervention and endorsements identified by this study was information about physiotherapy before joining the university, course duration, and availability of the classroom furniture. The efforts to raise physiotherapy student satisfaction in Ethiopia shall focus on creating awareness of the physiotherapy education program at the pre-college level and improving classroom facilities in the first place.

Keywords: teaching, learning, satisfaction, physiotherapy, student, Ethiopia

\section{Background}

Educational services that are provided by higher educational institutions are important service fields in any society and plays a unique role in societal development. Continuous evaluation of the educational process is one of the factors that assesses the success of higher education program. ${ }^{1,2}$ Besides, student satisfaction in a higher educational institution is as an indicator of institutional effectiveness. ${ }^{3}$

Understanding the factors that contribute to student satisfaction may lead to the improvement of educational inputs. The student's positive feelings and satisfaction
Correspondence: Melaku Hailu Temesgen Department of Physiotherapy, College of Health Sciences, Mekelle University, P.o.

Box: I87I, Mekelle, Ethiopia

Tel +25I 915862023

Email physiomelaku2008@gmail.com
Advances in Medical Education and Practice 2021:12 133-140

133 
are associated with the student's academic and social experiences that are acquired at the learning institution. $^{4-6}$ Student satisfaction is one of the major determinants for the success of the academic institution that helps to detect the areas that need improvement. ${ }^{4,7}$ In today's international educational market, higher education institutions must gain student satisfaction by analyzing the quality of service offered and provide sustainable highquality educational service. Quality education is the main pillar of sustainable reasonable advantage. ${ }^{8,9}$

How teaching becomes effective is the current point of discussion in the higher education community. ${ }^{10}$ Effective teaching aims at producing purposeful learning by creating a supportive learning environment, and continuous evaluation of the teaching and learning process helps to improve upon its effectiveness. ${ }^{10,11}$ The students' opinions and feedback are both rational and reliable sources of evidence to be an effective and efficient program in a University., ${ }^{3,12}$ Most of the prominent universities have a scheme of obtaining student's satisfaction surveys even after the completion of the program. ${ }^{13-15}$ However, University of Gondar as a pioneer of physiotherapy education in Ethiopia lacks in the evaluation of physiotherapy program. ${ }^{16}$

Universities' daily task is to increase the quality of their academic (teaching and learning process), research, and community services. At the same time, welfare services including suitable dormitories, libraries having adequate books, food services are the factors to create favorable conditions for students in order to make every effort to achieve their goals. ${ }^{7,17,18}$ Physiotherapy education emerged a decade ago in Ethiopia. ${ }^{16}$ To the best of the author's knowledge, there is a scarcity of empirical investigation and published reports about the teaching and learning process and influencing factors for students' satisfaction among physiotherapy students in Ethiopia. The findings of this study will have potential information to inform higher learning physiotherapy institutions about the factors that need to be addressed to improve the teaching and learning process. Therefore, this study was conducted to assess the satisfaction of the teaching and learning process and factors influencing satisfaction among physiotherapy students of the University of Gondar, Ethiopia.

\section{Methods}

\section{Study Period, Design, and Setting}

An institutional-based cross-sectional design was conducted from February to June 2018 at the University of
Gondar, College of Medicine and Health Sciences, Department of Physiotherapy. University of Gondar is a pioneer for physiotherapy education to train in a bachelor of degree in 2002. Since then more than 350 students have been graduated as physiotherapists from the university. Now it has undergraduate and postgraduate students with a full enrolment of four years and two years respectively.

\section{Study Participants}

All undergraduate (BSc) physiotherapy students at the University of Gondar were enrolled in the study. A total of 181 students were available at the Department of Physiotherapy, University of Gondar. Students, who had completed the registration in the physiotherapy course based upon the pre-requisite, signed the informed consent form, and physically able to mark the answers without any help were included in this study.

\section{Data Collection Tool and Procedure}

A self-administered questionnaire ( $\mathrm{N}=36$ items) was adopted from the University of Gondar learning and teaching satisfaction questionnaire ${ }^{19}$ and other related literature. ${ }^{15,20-22}$ In addition to that; socio-demographic variables, physiotherapy related information, and accessibility of compass facilities were also included in the questionnaire. The satisfaction questionnaire had five categories; teaching and learning strategies, evaluation methods of the students' performance, academic advising, evaluation of teacher and courses, and clinical training. Satisfaction was measured by a 5-point Likert scale (strongly disagree, disagree, neutral, agree, and strongly agree) and it was categorized into satisfied and dissatisfied by a summative scale. If the mean of one category was more than or equal to 3.4, it was leveled as satisfied, and if below 3.4 dis-satisfied. ${ }^{23}$ The understanding and clarity of the items included in the questionnaire were tested in a higher education centre. After the pilot run, modifications were made to improve the understanding of the items identified to be difficult. Ethical approval was granted by the Ethical review committee, University of Gondar. A detailed orientation of the survey objectives, procedures, possible outcomes. And benefits were explained to the participants. This study was conducted in accordance with the Declaration of Helsinki. ${ }^{24}$ The questionnaire was prepared in the English version and distributed to the students after the informed consent was signed. Data 
were collected by the post-graduate interns of physiotherapy from the University of Gondar.

\section{Data Analysis}

Data were entered and analyzed using Statistical Package for Social Sciences software version 21.0 (SPSS Inc., IBM Corp, Chicago, USA) for Windows. Descriptive statistics were computed using frequencies, distribution among variables, and significant factors for student teaching and learning satisfaction in physiotherapy education. Then study finding was explained using texts and frequency tables. Logistic regression analysis was used to predict the significantly associated variables for student satisfaction. A p-value of less than 0.05 was considered as a significant variable. STROBE (STrengthening the Reporting of OBservational studies in Epidemiology) cross-sectional reporting guidelines were used to assess the paper components of the manuscript. ${ }^{25}$

\section{Results}

\section{Socio-Demographic Characteristics of Physiotherapy Students}

A total of 173 students were convenient to participate in this study giving a 95.6\% response rate. Out of which 112 $(64.7 \%)$, were males. The majority of them $64(37 \%)$ were third-year students. Almost half of them 87 (50.3\%) had information about physiotherapy before joining university from friends, media, health institutions, and family. For more than half of the student's (57.8\%), physiotherapy program was not their primary preference of choice during their enrollment in the first year (Table 1).

\section{Student Satisfaction on the Learning and Teaching Process}

The overall satisfaction of students for the learning and teaching process was found to be $33.1 \%$ (CI: 27.4-39.9). Nearly one-third of the students $(32.1 \%)$, were satisfied with the teaching and learning strategies. Within this domain, the highest satisfaction point (36.4\%) was for the item "I am always updated about new research done in the area of my specialization" and the highest point of dissatisfaction (78.8\%) was for the "well-coordinated balanced teaching loads are given to me".

The cumulative satisfaction for clinical practice was found to be $32.9 \%$. Among this category, the participation of clinical expertise in clinical training has the highest satisfaction level (35.8\%). More than one-third
Table I Socio-Demographic Characteristics of Undergraduate Physiotherapy Students at the University of Gondar, Ethiopia $2018(\mathrm{~N}=173)$

\begin{tabular}{|c|c|c|c|}
\hline Variables & Female & Male & Total \\
\hline \multicolumn{4}{|l|}{ Age (year) } \\
\hline $18-20$ & $42(68.9 \%)$ & $36(32.1 \%)$ & 78 (45.1\%) \\
\hline$>20$ & $19(31.1 \%)$ & $76(67.9 \%)$ & 95 (54.9\%) \\
\hline \multicolumn{4}{|l|}{ Year of study } \\
\hline First year & $22(36.1 \%)$ & $24(21.4 \%)$ & $46(26.6 \%)$ \\
\hline Second year & 15 (24.6\%) & $23(20.5 \%)$ & 38 (22.0\%) \\
\hline Third year & 17 (27.9\%) & $47(42.0 \%)$ & 64 (37.0\%) \\
\hline Fourth year & 7 (II.5\%) & $18(16.1 \%)$ & 25 (14.5\%) \\
\hline \multicolumn{4}{|c|}{ Distance from home to university } \\
\hline I-400 kilo meter & $19(31.1 \%)$ & $60(53.6 \%)$ & 79 (45.7\%) \\
\hline 40I-999 kilo meter & $34(55.7 \%)$ & $35(31.2 \%)$ & 69 (39.9\%) \\
\hline$\geq 1000$ kilo meter & $8(13.1 \%)$ & 17 (I5.2\%) & 25 (I4.5\%) \\
\hline \multicolumn{4}{|l|}{ Sponsor for education } \\
\hline Self & $3(4.9 \%)$ & I (0.9\%) & $4(2.3 \%)$ \\
\hline Government & $58(95.1 \%)$ & III (99.1\%) & 169 (97.7\%) \\
\hline \multicolumn{4}{|c|}{ Information about physiotherapy before joining university } \\
\hline Yes & $37(60.7 \%)$ & $50(44.6 \%)$ & 87 (50.3\%) \\
\hline No & $24(39.3 \%)$ & $62(55.4 \%)$ & 86 (49.7\%) \\
\hline \multicolumn{4}{|c|}{ If yes, Source of info to join physiotherapy } \\
\hline Media & $14(23.0 \%)$ & $18(16.1 \%)$ & 32 (18.5\%) \\
\hline Friend & $10(16.4 \%)$ & $23(20.5 \%)$ & 33 (19.1\%) \\
\hline Family & $4(6.6 \%)$ & $2(1.8 \%)$ & $6(3.5 \%)$ \\
\hline Health institution & $9(14.8 \%)$ & 7 (6.2\%) & $16(9.2 \%)$ \\
\hline \multicolumn{4}{|c|}{ Was physiotherapy your primary preference } \\
\hline Yes & $24(39.3 \%)$ & $49(43.8 \%)$ & $73(42.2 \%)$ \\
\hline No & $37(60.7 \%)$ & $63(56.2 \%)$ & $100(57.8 \%)$ \\
\hline
\end{tabular}

of students (34.7\%) reported being satisfied with a domain of evaluation methods of the students' performance. From this domain, $38.7 \%$ of students reported to be satisfied with "the methods of student assessment procedures".

Among the categories, evaluation methods of the students' performance had the highest satisfaction (34.7\%), whereas, teaching and learning strategies and evaluations of teachers and course had the lowest satisfaction. Detailed description for all categories and each item of satisfaction for the learning and teaching process is displayed in Table 2. 
Table 2 Physiotherapy Students Satisfaction on the Teaching and Learning Process at the University of Gondar, Ethiopia 2018 (N=173)

\begin{tabular}{|c|c|c|}
\hline Items & Satisfied & Dissatisfied \\
\hline Satisfaction with the teaching and learning strategies (Category \#I) & $32.1 \%$ & $67.9 \%$ \\
\hline Adequate office hours provided by the teaching staff & $30.6 \%$ & $69.4 \%$ \\
\hline The methods used to help me scientifically & $30.1 \%$ & $69.9 \%$ \\
\hline I gained benefits from the scientific help of teaching staff & $30.1 \%$ & $69.9 \%$ \\
\hline Well-coordinated and balance teaching loads are given to me & $27.2 \%$ & $78.8 \%$ \\
\hline There are adequate and quality education tools in our program & $30.6 \%$ & $69.4 \%$ \\
\hline The methods and strategies used in the education program are good enough & $34.1 \%$ & $65.9 \%$ \\
\hline Various course are well coordinated to ensure equality among student & $35.8 \%$ & $64.2 \%$ \\
\hline The faculty members are keen enough on the completion of the course curriculum & $34.1 \%$ & $65.9 \%$ \\
\hline I am always updated about new research done in the area of my specialization & $36.4 \%$ & $63.9 \%$ \\
\hline Satisfaction on the academic advising (Category \#2) & $34.4 \%$ & $65.6 \%$ \\
\hline I have a good communication with students, alumni and recruiters & $43.9 \%$ & $56.1 \%$ \\
\hline I can get academic advise whenever I went & $29.5 \%$ & $70.5 \%$ \\
\hline There is well informative and important orientation program for new Students & $39.3 \%$ & $60.7 \%$ \\
\hline $\begin{array}{l}\text { Adequate and helpful explanation are given about the requirements of courses at the beginning of the semester was } \\
\text { helpful for the students. }\end{array}$ & $36.4 \%$ & $63.6 \%$ \\
\hline The university guide contribute a lot to facilitate my work and function & $28.9 \%$ & $71.1 \%$ \\
\hline The college guide contribute a lot to facilitate the work and function & $30.1 \%$ & $69.9 \%$ \\
\hline The section guide contributes a lot to facilitate the work and function & $34.7 \%$ & $65.3 \%$ \\
\hline The student guide contributes a lot for me by directing to deal with the university environment & $37.0 \%$ & $63.0 \%$ \\
\hline Satisfaction on the evaluation of teachers and courses (Category \#3) & $32.1 \%$ & $67.9 \%$ \\
\hline Teaching assistance and lecture eligible to teach. & $30.1 \%$ & $69,9 \%$ \\
\hline I can evaluate methods of teaches, teaching assistance and lecturers evaluation timely & $34.7 \%$ & $65.3 \%$ \\
\hline I do have a role in the evaluation of scientific and practical training courses & $34.7 \%$ & $65.3 \%$ \\
\hline The faculty member are using the potential as much as possible to improving the & $40.5 \%$ & $59.5 \%$ \\
\hline Faculty member has good ability in the educational process & $27.2 \%$ & $72.8 \%$ \\
\hline Adequate tools available to me to express the difficulties that I face with a faculty member & $23.7 \%$ & $76.3 \%$ \\
\hline Faculty member have a positive sprit toward me & $31.2 \%$ & $68.8 \%$ \\
\hline My faculty member have excellent in academic, practical and professional experiences & $35.8 \%$ & $64.2 \%$ \\
\hline Satisfaction on the evaluation methods of the students' performance (Category \#4) & $34.7 \%$ & $65.3 \%$ \\
\hline Method of student assessment mechanism & $38.7 \%$ & $61.3 \%$ \\
\hline I see effective results of the student assessment to the program & $30.6 \%$ & $69.4 \%$ \\
\hline Mechanism of fraud control in the students' duties and tests & $30.6 \%$ & $69.4 \%$ \\
\hline Test materials, methods of results review, and correction of answer sheet are good enough & $38.7 \%$ & $61.3 \%$ \\
\hline Satisfaction on the clinical/practical training (Category \#5) & $32.9 \%$ & $67.1 \%$ \\
\hline Participation of clinical/practical expertise in clinical training. & $35.8 \%$ & $64.2 \%$ \\
\hline Experience of the students in hospital clinical/practical training & $32.9 \%$ & $67.1 \%$ \\
\hline Benefits gained by the students during hospital clinical/practical training & $30.6 \%$ & $69.4 \%$ \\
\hline Mechanisms of preparation of the students for hospital clinical/practical training & $32.4 \%$ & $67.6 \%$ \\
\hline Suitability of clinical/practical training situations for training goals & $32.9 \%$ & $67.1 \%$ \\
\hline Benefits gained by the students from the supervisors in the clinical/practical training sites & $32.5 \%$ & $67.5 \%$ \\
\hline
\end{tabular}

\section{Accessibility of Facilities for Students}

Regarding the accessibility of facilities, more than half (58.4\%) of the students were agreed with the accessibility of library service. Majority $(60.1 \%)$ of them, reported that they disagree with the classroom furniture accessibility of the University (Table 3).

\section{Factors Associated with Students' Satisfaction}

In bivariate logistic regression analysis, student satisfaction was significantly associated with; years of study, information about physiotherapy before joining the university, accessibility of classroom furniture, distance from 
Table 3 Facility Accessibility for Physiotherapy Students at the University of Gondar, Ethiopia 2018 (N=173)

\begin{tabular}{|l|l|l|}
\hline Variables & Agree & Disagree \\
\hline Rich and updated library services & $58.4 \%$ & $41.6 \%$ \\
Sufficient ICT services & $48.6 \%$ & $51.4 \%$ \\
Well-equipped classroom furniture & $39.9 \%$ & $60.1 \%$ \\
Sufficient recreational facilities & $27.2 \%$ & $72.8 \%$ \\
Adequate dormitory facilities & $32.9 \%$ & $67.1 \%$ \\
Adequate food-related service & $19.1 \%$ & $80.1 \%$ \\
Participating in a club in your campus (yes/no) & $20.2 \%$ & $79.8 \%$ \\
\hline
\end{tabular}

home to the university, accessibility of information communication technology (ICT) services, and accessibility of library services. However, in multivariate logistic regression analysis, students' satisfaction was significantly associated with years of study $[\mathrm{AOR}=0.12, \quad 95 \%$ CI $(0.02-0.67)]$, information about physiotherapy before joining university $[\mathrm{AOR}=6.25,95 \%$ CI $(2.19-17.79)]$, and accessibility of well-equipped classroom furniture $[\mathrm{AOR}=0.05,95 \% \mathrm{CI}(0.04-0.66)]$ as displayed in Table 4 .

\section{Discussion}

The study aimed to assess students' satisfaction in their learning and teaching process at the Physiotherapy Department, University of Gondar. The overall satisfaction for five categories of teaching and learning process was $33.1 \%$, representing a low satisfaction for the students towards their learning and teaching process. In particular, the findings of this study also showed that the student's satisfaction for clinical training was 32.9 , which is also a major concern. This is consistent with a study done in Ghana, which assessed the student's satisfaction with the quality of service offered by the public higher education institutions. ${ }^{26}$ However, this result was lower than the

Table 4 Factors Associated with Satisfaction of Physiotherapy Students at the University of Gondar, Ethiopia 2018 (N=173)

\begin{tabular}{|c|c|c|c|c|c|}
\hline \multirow[t]{2}{*}{ Variables } & \multicolumn{2}{|c|}{ Satisfaction } & \multirow[t]{2}{*}{ COR $(95 \% \mathrm{Cl})$} & \multirow[t]{2}{*}{ AOR (95\% Cl) } & \multirow[t]{2}{*}{ p-value } \\
\hline & Satisfied & Not Satisfied & & & \\
\hline \multicolumn{6}{|l|}{ Year of study } \\
\hline First year & 14 & 32 & $5.10(1.34-19.41)$ & $0.30(0.05-1.73)$ & 0.179 \\
\hline Second year & 3 & 35 & $0.64(0.29-1.43)$ & $1.20(0.18-8.23)$ & $0.85 I$ \\
\hline Third year & 26 & 38 & $2.30(0.67-7.94)$ & $0.12(0.02-0.67)$ & $0.016^{*}$ \\
\hline Fourth year & 4 & 21 & I ref & I ref & \\
\hline \multicolumn{6}{|c|}{ Distance from home to the university } \\
\hline $\mathrm{I}-400 \mathrm{~km}$ & 25 & 54 & $1.99(0.79-4.99)$ & $1.76(0.58-5.39)$ & 0.319 \\
\hline $400-999 \mathrm{~km}$ & 10 & 59 & $5.45(1.94-15.28)$ & $0.51(0.13-2.09)$ & 0.351 \\
\hline$\geq 1000 \mathrm{~km}$ & 12 & 13 & I ref & I ref & \\
\hline \multicolumn{6}{|c|}{ Information about physiotherapy before joining university } \\
\hline Yes & 35 & 52 & $4.15(1.97-8.75)$ & $6.25(2.19-17.79)$ & $0.001 *$ \\
\hline No & 12 & 74 & I ref & I ref & \\
\hline \multicolumn{6}{|c|}{ Rich and updated library service } \\
\hline Disagree & 13 & 59 & $4.74(1.32-16.96)$ & $1.57(0.17-14.40)$ & 0.690 \\
\hline Agree & 34 & 67 & I ref & I ref & \\
\hline \multicolumn{6}{|c|}{ Sufficient information communication technology service } \\
\hline Disagree & 16 & 73 & $4.21(1.31-13.51)$ & $4.76(0.53-42.59)$ & 0.163 \\
\hline Agree & 31 & 53 & I ref & I ref & \\
\hline \multicolumn{6}{|c|}{ Well-equipped class room furniture } \\
\hline Disagree & 19 & 85 & $2.22(0.57-8.66)$ & $0.05(0.04-0.66)$ & $0.023 *$ \\
\hline Agree & 28 & 41 & I ref & I ref & \\
\hline
\end{tabular}

Note: $*_{p}<0.05$ Significant.

Abbreviations: km, kilometer; $\mathrm{AOR}$, adjusted odds ratio; $\mathrm{Cl}$, confidence interval; $\mathrm{COR}$, crude odds ratio. 
international students satisfaction ${ }^{27}$ and physiotherapy students of Taif University, Saudi Arabia. ${ }^{28}$ The possible reasons could be that physiotherapy education in Ethiopia is relatively new when compared to the other countries. ${ }^{12}$ Lack of experienced faculty members and awareness about the program might have influenced these results. In this study, almost half of the students reported that they never knew about physiotherapy before joining the program.

In this study, students were dissatisfied with the teaching and learning strategies, with the evaluation of academic advising, evaluation of teachers and courses, and evaluation methods of the students' performance. In contrast, the study done in Brazil found that the students were satisfied with the evaluation of the course. ${ }^{12}$ The reasonable explanation for students' satisfaction could be mediated by teacher skills, methods of effective knowledge-sharing quality, and experience. For instance, in Brazil, the qualification of the teaching staff was covered by a larger number of Masters and Ph.D. holders which might bring didactic and pedagogical innovations. At the same time, the lack of experienced clinical experts and particularly Ph.D. holders in the physiotherapy academic program in Ethiopia might be one of the reasons for most of the study participants not being satisfied with the teaching and learning strategy. Further, teacher's experience and qualifications are the strongest predictors of student satisfaction. ${ }^{4,29}$ Clinical programs like physiotherapy need clinical experts with vast experience and higher educational attainment like a Ph.D. as that brings a more clinical approach to the course. Besides being physiotherapists they should be trained in teaching and assessment. Further, the satisfaction of the higher education institution with the graduates is always good to know and reflects the quality of the course.

This study revealed that students who had information about physiotherapy before joining the university were six times more likely to be satisfied compared with those who had no information. Previous information about your future career is the most important thing for a major preference during department selection that makes a decision based on your interest. Student's satisfaction in their primarily preferred courses may have a positive attitude towards the careers emanating from their preferred courses of choice based on their aptitude during selecting the undergraduate program. ${ }^{30}$ However, in this study physiotherapy was not their primary preference for more than half of the students during the selection of department. This could be due to the way students joining their major profession which was based on the school grades, not their aptitude or interests and this is mostly the nature of higher education in Ethiopia. In line with this, majority of the Korean physiotherapy students those who selected their department based on their aptitude or interests reported higher satisfaction compared to those who did have interest. ${ }^{20,31}$

In this study, students who were in their third year were $88 \%$ less likely to be satisfied compared with those who had studied in the fourth year. This finding is similar to the studies conducted in Saudi Arabia and Jordan, where the year of study in the physiotherapy program influenced the reported level of satisfaction among students. $^{32,33}$ The possible reasons could be, due to increasing the sense of being a professional. It is believed that a sense of support for more patients that students deliver during their training will upgrade their selfreliance as a professional as they become more senior. ${ }^{32}$

Students who had disagreed on the availability of wellequipped classroom furniture were $50 \%$ more likely not to be satisfied compared with those who were agreed students. Similarly, a case study in 2018, reporting "Student Satisfaction Regarding Service Quality at an Ethiopian Public Higher Education Institutions" revealed that the service quality was perceived by students to be very poor and this was reflected by their low satisfaction scores. ${ }^{34}$ Conversely, majority of the students from Dire Dawa University were satisfied with the service that the university offers. ${ }^{35}$ Generally, the availability of infrastructure facilities at university are an important and significant factor for student teaching and learning satisfaction. ${ }^{36-38}$

\section{Limitation}

It is plausible that some limitations might have influenced the results obtained. First, this is a snapshot study and may not show variations over time on the teaching and learning process and the level of students' satisfaction. Secondly, there were no comparison of the results of physiotherapy students with other students from similar facilities. Hence, the findings of this study may not suggest if the students are actually symptomatic of University satisfaction rather than physiotherapy profession-specific. Another possible source of limitation is satisfaction measuring tools may not be reliable across different countries and students.

\section{Conclusion}

In this study, the low overall student satisfaction and in particular for the clinical training is a major concern. The 
main determinants contributing negatively to the students satisfaction are lack of information about physiotherapy before joining the University, year of study, and unavailability of the furniture in the classroom. The efforts to raise physiotherapy student satisfaction in Ethiopia the higher education institutions shall design initiatives to create awareness of the physiotherapy education program at the pre-college level and improve classroom facilities in the first place.

\section{Abbreviations}

AOR, Adjusted Odds Ratio; COR, Crude Odds Ratio; OR, Odd's Ratio; PT, Physiotherapy.

\section{Data Sharing Statement}

All data relevant to our findings are contained within the manuscript. The full dataset contains sensitive participant information. Requests for further details on the dataset and queries concerning data sharing shall be addressed to the corresponding author.

\section{Ethics Approval and Consent to Participate}

Ethical approval was granted by the Ethical Review Committee of the University of Gondar College of Health Sciences and written consent was obtained from all the participants.

\section{Acknowledgments}

We are grateful to the College of Medicine and Health Sciences, the University of Gondar for allowing doing this research. We would like to express our special thanks to all study participants for sparing their time during data collection, and the authors thank the Department of Physiotherapy, University of Gondar for providing us all the necessary information.

\section{Author Contributions}

All the authors made a significant contribution in the conception of the idea, proposal, study design, execution, acquisition of data, analysis, and interpretation, or in all these areas; took part in drafting, revising, or critically reviewing the article; gave final approval of the version to be published; have agreed on the journal to which the article has been submitted; and agree to be accountable for all aspects of the work.

\section{Funding}

There was no funding for this research.

\section{Disclosure}

Authors declare that they have no conflict of interest.

\section{References}

1. Motefakker N. The study of the level of satisfaction of the students of the faculty of social sciences with welfare services of Imam Khomeini International University of Qazvin. Proce Econ Finance. 2016;36(1):399-407. doi:10.1016/S2212-5671(16)30052-1

2. Woodall T, Hiller A, Resnick S. Making sense of higher education: students as consumers and the value of the university experience. Studies Higher Educ. 2014;39(1):48-67. doi:10.1080/03075079.2011.648373

3. Jurkowitsch S, Vignali C, Kaufmann H-R. A student satisfaction model for Austrian higher education providers considering aspects of marketing communications. Innovative Marketing. 2006;2(3):9-23.

4. Santini F, De O, Ladeira WJ. Student satisfaction in higher education: a meta-analytic study. J Marketing Higher Edu. 2017;27(1):1-18. doi:10.1080/08841241.2017.1311980

5. Elliott KM, Shin D. Student satisfaction: an alternative approach to assessing this important concept. J Higher Educ Policy Manage. 2002;24(2):197-209. doi:10.1080/1360080022000013518

6. Daniel D, Liben G, Adugna A. Assessment of Students' satisfaction: a case study of dire dawa university, Ethiopia. J Educ Pract. 2017;8 (4):111-120.

7. Chandramohan S. Student satisfaction through service quality a review on higher education sector. Arch Business Res. 2019;7 (7):242-249.

8. Vaughan ND, Cleveland-Innes M, Garrison DR. Teaching in Blended Learning Environments: Creating and Sustaining Communities of Inquiry. Athabasca University Press; 2013.

9. Miclea M. "Learning to do" as a pillar of education and its links to entrepreneurial studies in higher education: European contexts and approaches. Higher Educ Eur. 2004;29(2):221-231. doi:10.1080/ 0379772042000234857

10. Kivunja C. Innovative pedagogies in higher education to become effective teachers of 21 st century skills: unpacking the learning and innovations skills domain of the new learning paradigm. Int $J$ Higher Educ. 2014;3(4):37-48. doi:10.5430/ijhe.v3n4p37

11. Devlin M, Samarawickrema G. The criteria of effective teaching in a changing higher education context. Higher Educ Res Dev. 2010;29 (2):111-124. doi:10.1080/07294360903244398

12. Fadel CB, Souza JAD, Bordin D, Garbin CAS, Garbin AJI, Saliba NA. Satisfaction with the academic experience among graduate students of a Brazilian public university. RGO Rev Gaúcha De Odontologia. 2018;66(1):50-59. doi:10.1590/1981863720180001000073261

13. Duarte PO, Raposo MB, Alves HB. Using a satisfaction index to compare students' satisfaction during and after higher education service consumption. Tertiary Educ Manage. 2012;18(1):17-40. doi:10.1080/13583883.2011.609564

14. Murray J, Kidd W, McMahon A, Viswarajan S. Teacher Educators and Expansive Learning in the Workplace and Beyond. Front Media. 2020.

15. Kim J. A Study on Vocational Personality Types, Major Satisfaction and Accomplishments of Students Majoring in Physical Therapy. Catholic University of Pusan; 2011.

16. Footer CB, Tsegaye HS, Yitnagashaw TA, et al. Empowering the physiotherapy profession in Ethiopia through leadership development within the doctoring process. Fron Public Health. 2017;5:51. doi:10.3389/fpubh.2017.00051 
17. El-Hilali N, Al-Jaber S, Hussein L. Students' satisfaction and achievement and absorption capacity in higher education. Proce Soc Behav Sci. 2015;177:420-427. doi:10.1016/j.sbspro.2015.02.384

18. Farahmandian S, Minavand H, Afshardost M. Perceived service quality and student satisfaction in higher education. $J$ Business Manage. 2013;12(4):65-74.

19. University of Gondar Official Website [Internet]. 2021. Available from: http://www.uog.edu.et/.

20. Kim S-Y, Kim C-H, Song J-Y, Ahn D-H, Chae J-B. An investigation of factors which influence physical therapy students' satisfaction with their clinical practice. Physical Therapy Korea. 2004;11(3):71-84.

21. Alahmari K, Shanker J, Gular K. Physical therapy student's satisfaction during their practical and clinical training sessions at Abha, Saudi Arabia. Cross Sec Study General Professional Educ. 2017;2017(1):3-7.

22. Milanese S, Gordon S, Pellatt A. Undergraduate physiotherapy student perceptions of teaching and learning activities associated with clinical education. Physical Therapy Rev. 2013;18(6):439-444. doi:10.1179/1743288X12Y.0000000060

23. Bhatti Z, Javed A. Evaluation Of Overall Satisfaction Level among the Students of Physiotherapy (Under Graduate \& Post Graduate) Enrolled In different Physiotherapy Institute of The Pakistan. Int J Rehabilitation Sci. 2018;1(02):36-42.

24. Williams JR. The Declaration of Helsinki and public health. Bull World Health Organ. 2008;86:650-652. doi:10.2471/BLT.08.050955

25. Knottnerus A, Tugwell P. STROBE-a checklist to Strengthen the Reporting of Observational Studies in Epidemiology. $J$ Clin Epidemiol. 2008;61(4):323. doi:10.1016/j.jclinepi.2007.11.006

26. Eshun E, Badu A, Korwu P. Impact of Service Quality on Students ${ }^{-}$ Satisfaction in a Ghanaian Public Tertiary Institution. Int $J$ Learn Dev. 2018;8(3):97-112. doi:10.5296/ijld.v8i3.13447

27. Alemu AM, Cordier J. Factors influencing international student satisfaction in Korean universities. Int $J$ Educ Dev. 2017;57:54-64. doi:10.1016/j.ijedudev.2017.08.006
28. Alghamdi AR, Alzahrani SS, Abdel-aziem AA. Physiotherapy Students Satisfaction to Learning and Teaching. BMC. 2017;7 (1):23-35.

29. Aslam U, Rehman M, Imran MK, Muqadas F. The impact of teacher qualifications and experience on student satisfaction: a mediating and moderating research model. Pakistan J Commerce Soc Sci. 2016;10 (3):505-524.

30. Lim E-M, Park S-M, Eom Y-S. The differences of college students' department and job selection, major satisfaction according to career indecision. Korean Youth Res. 2009;16(1):33-50.

31. Kim YL, Lee SM. Effect of satisfaction in major at university on academic achievement among physical therapy students. J Phys Therapy Sci. 2015;27(2):405-409. doi:10.1589/jpts.27.405

32. Hawamdeh MM, Mansour Z, Al-nassan S, Hawamdeh Z. 4 Th Year Physical Therapy Students Satisfaction in Jordanian Universities: A Survey Study. fizojoterapia Polska; 2018.

33. Alahmari K, Jaya Shanker KG. Physical therapy student' $\mathrm{s}$ satisfaction during their practical and clinical training sessions at abha, Saudi Arabia. General Professional Educ. 2017;3-7.

34. Lodesso SL, Van NEJ, Jansen CA, Muller H. Student satisfaction regarding service quality at Ethiopian public higher education institutions: a case study. J Stud Affairs Africa. 2018;6(2):51-64.

35. Daniel D, Liben G, Adugna A, Scienes C. Assessment of students ' satisfaction: a case study of dire dawa. BMJ. 2017;8(4):111-120.

36. Milanese S, Gordon S, Pellatt A. Undergraduate physiotherapy student perceptions of teaching and learning activities associated with clinical education. 2013;439-444.

37. Kaur H. Satisfaction of Students towards quality in higher educationa study of higher education sector Punjab (India). Pacific Bus Rev Int. 2015;8(6):83-91.

38. Weerasinghe IMS, Lalitha R, Fernando S. Students 'Satisfaction in Higher Education Literature Review. 2018.
Advances in Medical Education and Practice

\section{Publish your work in this journal}

Advances in Medical Education and Practice is an international, peerreviewed, open access journal that aims to present and publish research on Medical Education covering medical, dental, nursing and allied health care professional education. The journal covers undergraduate education, postgraduate training and continuing medical education including emerging trends and innovative models linking education, research, and health care services. The manuscript management system is completely online and includes a very quick and fair peer-review system. Visit http://www.dovepress.com/testimonials.php to read real quotes from published authors. 